\title{
Conference of Presidents of Negro Land-Grant Colleges
}

$\mathrm{T}$ HE PROBLEMS of land-grant college librarians were given attention at the twenty-second annual Conference of Presidents of Negro Land-Grant Colleges at Chicago on Oct. 24-26, 1944. The following is a brief résumé:

Mrs. Ruby E. Stutts Lyells, librarian of Alcorn College, opened with a discussion of "The Library in Negro Land-Grant Colleges." She considered finance, physical property, book collections, periodicals, personnel, and the use of books by students.

Following Mrs. Lyells, informal talks were given by Robert B. Downs, director of libraries at the University of Illinois, and Charles H. Brown, librarian of Iowa State College. ${ }^{1}$ Mr. Downs outlined the functions of the college library. $\mathrm{He}$ also listed the reasons for the considerable growth of the modern library movement as follows: (I) the enlargement of the curricula in medicine and law and the development of new teaching fields; (2) the recognition of the importance of collecting certain materials, such as state, federal, municipal, and foreign documents; and the demands of the social sciences and the large enrolments in these fields; (3) the breaking down of old teaching methods by the requirements of mass education; (4) the trend away from specialization and the spread of survey courses; and (5) the increased demands

\footnotetext{
1 Mr. Brown's remarks are incorporated in part in
} his more general article appearing on pages ror.05. on the library now made by research.

Eliza Atkins Gleason, director of the Atlanta University Library School, spoke on the subject, "The College President and the Library" and discussed the responsibilities of the president to the library. First, the president must take the lead in setting up the program; he must know the total purpose of the institution and fix the place of the library within it. Second, he is responsible for the selection of a good librarian.

As to the third responsibility, it should be made possible for the librarian to know the shifts and changes in the educational philosophy of the institution and to be supported by an efficient staff, with classification, tenure, and salaries adjusted to integrate library workers into the faculty with equal rank and compensation. Also, the library budget, a combined undertaking of the president, board, and librarian, must be initiated by the president.

Following this speaker a round table discussion on the goals of the college library was held. Seven librarians participated, with M. D. Sprague, of Tuskegee, as leader. Discussion centered in the following topics: finances and budgets, personnel problems, library quarters and buildings, and the library committee.

-James A. Hulbert, Librarian, Virginia State College for Negroes 